\title{
べき逆ガウス型分布とその応用
}

\begin{tabular}{llll} 
広島大 工学部 & 岩 瀬 晃 盛 \\
\hline 統計数理研究所 & 平 野 勝 臣
\end{tabular}

\section{Power Inverse Gaussian Distribution and Its Applications}

\author{
Kōsei IwasE and Katuomi HIRANo
}

| |||||||||||||||||||||||||||||||||||||||||||||||||||||||||||||| 要 旨 |||||||||||||||||||||||||||||||||||||||||||||||||||||||||||||||

正の值をとる確率変数の分布の諸特徵を考察する．特に逆ガウス型分布, 対 数正規分布，ガンマ分布などが持っているある共通の性質に注目する．この性 質を保ち，べき変換に関して分布が閉じているように一般化された，対数正規 分布を含む，べき逆がウス型分布を定義し，その性質を調べる。これらの応用 として乗法的に外乱が加わった回㷌モデルを導入する。

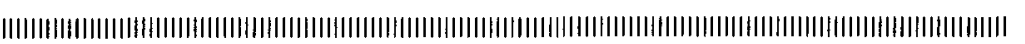

\section{1. はじめに}

単調に变化する量の変化速度, 容器中の物質の濃度, 密度を測る現象を考它よう。これらの計 測では $2 つ の$ 観測の方法がある。例えば，速度でいえば，あらかじめ定められた単位時間内に進 んだ距離の測定と，あらかじめ定められた単位距離を走行するに要した時間の測定とである. 現 実には，前者ではなくて後者のデータが得られることが多い．これはあらかじめ測定区間を定め て牤く方が観測条件を設定しやすいことによる。このように単位としては逆数の関係にあって,一 方の単位の計測值しか得られないとき，もら一方の単位の現象として解析したいことがある。す なわち, 確率変数とその逆数がそれぞれ意味を持ち, それらの分布を用いて現象の解析が要求さ れる場合である。

本稿では正值連続的確率变数の従らスケール分布族 $\{(1 / \mu) g(x / \mu)\}$ を扱ら. 慣例に従って $\mu$ を $X$ の尺度母数と呼ぶことにする。 また する現象」と呼び，この こを尺度母数として持っ $X$ を「尺度 $\mu$ を記述する確率変数」と呼ぶこと にする.Xの単位は $\mu$ の単位によって決定される。本稿の目的は尺度を記述する確率变数の分布 として有用なものを新たに導入し，その性質を調べ，さらにこの分布の応用について述べること である.

Key words: B-S distribution, Coefficient of variation, Gamma distribution, Inverse Gaussian distribution, Lognormal distribution, Loss function, Power normal distribution, Regression, Scale parameter, Transformations to normality. 
対数正規分布と逆ガウス型分布は，これに従ら確率变数の逆数がそれぞれ同じ形の分布に従ら。 対数正規分布の場合，さらにゼロでない実数のべき乗をしても再び対数正規分布に従ら。これら は上で述べた観点から都合の良い性質であり利用したい．対数正規分布の場合，その根拠は，正 值確率変数を対数変換したものが正規分布に彷うということに基づいている，そこで本稿ではあ る単調変換を用いて，確率変数のべき乗に関して閉じているという性質を保存し，対数正規分布 を含む，逆ガウス型分布を一般化した分布としてべき逆ガウス型分布を導入する．さらにこの分 布の性質および回帰の問題への適用を議論する。

つぎの章では, まず尺度を記述する分布としてガンマ分布, 対数正規分布, Birnbaum-Saunders 分布 (Birnbaum and Saunders (1969)，以後 B-S 分布と略記)，扣よび逆ガウス型分布（この分 布については例えば，Chhikara and Folks (1989) を参照されたい)をとりあげ，これらの分布 の尺度母数に関する損失関数の分布がカイ二委分布と関連づけられることを指摘する。むた，こ れらの分布に從ら確率変数を尺度母数で無名数化したもののバラッキと, 非対称の度合いを示す 母数について議論する. 従来正值確率変数のバラッキを表するのとして利用されてきた变動係数 との関係についても言及する。

3 章では, 対数正規分布のように, 変換後の分布が標準正規分布に従うようないくつかの分布と 変換を考察する。この結果を用いて，ある特定の損失関数の分布がカイ二乗分布に従うとの条件 と，ゼロでない任意のべき乗に関して分布が閉じているとの条件を満たす正の領域で定義される 新しい分布として，べき逆ガウス型分布を導入する。この分布はもはや変換によって直接標準正 規分布とは結びつかない.4章でこの分布のいくつかの性質を与える．5章ではこの分布を誤差 (正確には誤比)として持つ原点を通る回鹵曲線について論ずる。これは説明変数, 従属変数いら れも正の值しかとらない状況の下での回帰モデルである。6章ではいくつかの関連する事項を議 論する。

\section{2. 尺度母数と損失関数}

確率変数 $X$ が尺度 $\mu$ を記述する場合, $X$ の $\mu$ のまわりのバラッキ，あるいは損失を $X / \mu$ の関 数で測ることは自然である。この場合, 損失関数 $L(X, \mu)$ として二乗損失関数 $(X / \mu-1)^{2}$ を用い ることは望ましくない. 尺度母数 $\mu$ からのずれが $X=0$ のときと， $X=2 \mu$ のとさとで損失が等し

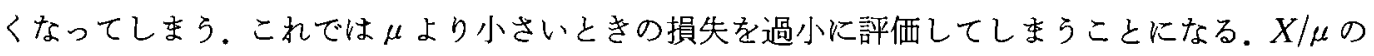
関数で, 1 に関して損失の意味で対称な損失関数を用いたい.このような $L(X, \mu)$ として, 次の ものが考觉られる：

$$
\frac{X}{\mu}-1-\log \frac{X}{\mu}, \quad\left(\frac{X}{\mu}-1\right) \log \frac{X}{\mu}, \quad\left(\log \frac{X}{\mu}\right)^{2}, \quad\left(\sqrt{\frac{X}{\mu}}-\sqrt{\frac{\mu}{X}}\right) \log \frac{X}{\mu}, \quad \frac{X}{\mu}+\frac{\mu}{X}-2 .
$$

最初の損失関数は特定な分布（例学ば正規分布や指数分布）を指定して，カルバックーライブラー

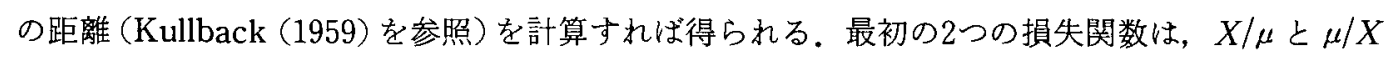
のどちらで測っても同じ值であるといら対称性に欠ける.

本稿で扱らガンマ分布，対数正規分布，B-S 分布扣よび逆ガウス型分布の確率素分を以下に示 す. 普通に用いられている表現と異なるが，その理由はあとで述べる。 
ガンマ分布 $G a\left(\mu, c^{2}\right): \frac{1}{\Gamma\left(1 / c^{2}\right)}\left(\frac{1}{c^{2}}\right)^{1 / c^{2}}\left(\frac{x}{\mu}\right)^{\left(1 / c^{2}\right)-1} \exp \left(-\frac{1}{2 c^{2}} \frac{2 x}{\mu}\right) \frac{d x}{\mu}$.

対数正規分布 $L N\left(\mu, c^{2}\right): \frac{1}{\sqrt{2 \pi} c}\left(\frac{x}{\mu}\right)^{-1} \exp \left\{-\frac{1}{2 c^{2}}\left(\log \frac{x}{\mu}\right)^{2}\right\} \frac{d x}{\mu}$.

B-S 分布 $B S\left(\mu, c^{2}\right): \frac{1}{2 \sqrt{2 \pi} c}\left\{1+\frac{x}{\mu}\right\}\left(\frac{x}{\mu}\right)^{-3 / 2} \exp \left\{-\frac{1}{2 c^{2}}\left(\sqrt{\frac{x}{\mu}}-\sqrt{\frac{\mu}{x}}\right)^{2}\right\} \frac{d x}{\mu}$.

逆ガウス型分布 $I G\left(\mu, c^{2}\right): \frac{1}{\sqrt{2 \pi} c}\left(\frac{x}{\mu}\right)^{-3 / 2} \exp \left\{-\frac{1}{2 c^{2}}\left(\sqrt{\frac{x}{\mu}}-\sqrt{\frac{\mu}{x}}\right)^{2}\right\} \frac{d x}{\mu}$.

これらはスケール分布族の典型的な例であり，尺度母数 $\mu$ は，ガンマ分布と逆がウス型分布で は母平均, 対数正規分布と B-S 分布では母中央值である. 自由度 $n$ のカイ二乗分布を $\chi^{2}(n)$ と書 くとき，次の性質がある：

$$
\begin{gathered}
X \sim G a\left(\mu, c^{2}\right) \text { のとき } 2 X / \mu \sim c^{2} \chi^{2}\left(2 / c^{2}\right), \\
X \sim L N\left(\mu, c^{2}\right) \text { のき }\left(\log \frac{X}{\mu}\right)^{2} \sim c^{2} \chi^{2}(1) \\
X \sim B S\left(\mu, c^{2}\right) \text { のを }\left(\sqrt{\frac{X}{\mu}}-\sqrt{\frac{\mu}{X}}\right)^{2} \sim c^{2} \chi^{2}(1), \\
X \sim I G\left(\mu, c^{2}\right) \text { のき }\left(\sqrt{\frac{X}{\mu}}-\sqrt{\frac{\mu}{X}}\right)^{2} \sim c^{2} \chi^{2}(1) .
\end{gathered}
$$

最後の事実はShuster (1968) による.これらの結果は各確率素分の $\exp$ の中の主因子の $x$ に $X$

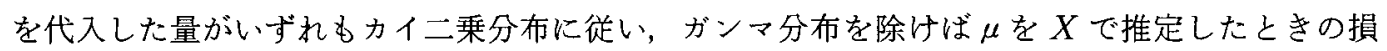
失が自由度 1 のカイ二乗分布に従っていることを意味している，確率素分を書き換えた理由がこ れである.我々はこの性質に注目し，3章で新しい分布を導くとき利用する。

上で述べた性質に於いて，c は各損失関数を基準化するための母数と考えられ，尺度母数 $\mu て ゙$ 無名数化された確率変数の従う分布のバラッキ，拡がり，非対称性の程度などを表すと解积され る. 実際, ガンマ分布と逆ガウス型分布の場合, c は母変動係数であり, 対数正規分布と B-S 分 布の場合には $c か ゙ 1$ と比べて小さいとさやはり $c$ は母変動係数とほぼ等しい.これは正值確率変 数の実現值の特性をとらえるために標本变動係数が有効であることに関連していると思われる。 例えば津村ら（1988）を見よ。

尺度を記述する確率变数の分布の例としてガンマ分布はよく知られている。しかし他の3つの 分布との異質性（上の性質で自由度が 1 でないこと）により，考察の対象から外す。な拉，ガン マ分布に従ら確率変数の逆数は一般には母平均が存在しない（母平均が存在しなければならない と言う理由は一般的には無いだろうが).

\section{3. 典型的諸分布の比較}

この章では,はじめに正の值をとる確率変数のある变数変換が正規分布に従うような変換と, 確 率分布について調べる. 次に, 正規分布への変換といら要請をゆるめて, 変換後の 2 乗の分布が カイ二乗分布となり，且つゼロでないべき乗に関して分布が閉じているような確率分布としてべ き逆ガウス型分布を導く。この過程で諸分布の関係を述べる.

やや天下りではあるが, 


$$
(X-\mu) F(1-\lambda, \beta ; 2 \beta ; 1-(X / \mu)), \quad X>0, \quad \mu>0, \quad \beta \neq 0
$$

を考克る。ここで $F$ はガウスの超幾何関数である，この変換は一般に単調ではないが，単調とな るよらな $\lambda$ るの特別な值の組み合わせに関心がある。さて, 変換 $(1)$ は変換の前後で同一の単

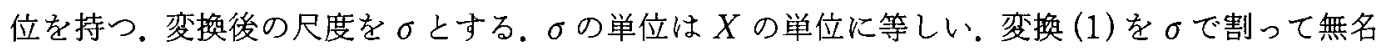

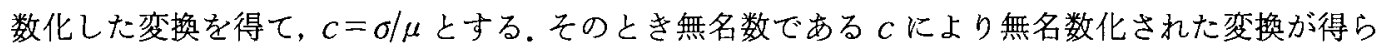
れる。この変換後の従ら分布が標準正規分布に従らときの確率変数 $X$ の分布，すなわち

$$
(1 / C)((X / \mu)-1) F(1-\lambda, \beta ; 2 \beta ; 1-(X / \mu)) \sim N(0,1)
$$

であるときの $X$ の分布を考察しょう。

(2) 式で $\lambda=0, \beta=1$ とすると

$$
\frac{\log (X / \mu)}{C} \sim N(0,1)
$$

を得る. (3) が成り立つときの $X$ の従う分布を対数正規分布と云い, 記号で $X \sim L N\left(\mu, c^{2}\right)$ と記 す。これは通例の定義と $\mu$ の意味が違 $(6$ 章参照)。確率素分は 2 章で与えた。この分布で $\mu$ は $X$ の尺度母数であり，母中央值でもある. $c$ は $\log (X / \mu)$ の母標準偏差になっている. また逆数の 分布については $1 / X \sim L N\left(1 / \mu, c^{2}\right)$ ，さらに一般に $X^{r} \sim L N\left(\mu^{r},(r c)^{2}\right)$ である.

(2) 式で $1-\lambda=2 \beta$ とすると

$$
\frac{1}{C}\left(\frac{X}{\mu}\right)^{\frac{\lambda}{2}}\left(\sqrt{\frac{X}{\mu}}-\sqrt{\frac{\mu}{X}}\right) \sim N(0,1)
$$

を得る.この変換は $-1<\lambda<1$ のさ， $(0, \infty)$ から $(-\infty, \infty) へ の X$ 単調増加関数になって いる。特に $\lambda=0$ のとき,

$$
\frac{1}{c}\left(\sqrt{\frac{X}{\mu}}-\sqrt{\frac{\mu}{X}}\right) \sim N(0,1)
$$

を得る. (5)で定義される $X$ の分布が $\mathrm{B}-\mathrm{S}$ 分布である. 確率素分は前章で与えた。この分布は $X$ $\sim B S\left(\mu, c^{2}\right)$ のを， $X^{-1} \sim B S\left(\mu^{-1}, c^{2}\right)$ となり，逆数変換に関して分布が閉じている.

(2) 式で $\beta=1$ だけの条件を与学ると，対数正規分布の一つの一般化

$$
\frac{1}{C} \cdot \frac{1}{\lambda}\left\{\left(\frac{X}{\mu}\right)^{2}-1\right\}
$$

となる.この変換は Box-Cox のべき変換である.ところがこれは $X>0$ に対して実数全体の值を とらないので，打ち切られた標準正規分布に従らとすることによりべき正規分布を定義する。こ

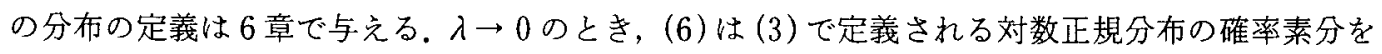
与える。

べき正規分布は変換後の分布が標準正規分布となるとの方針に外れるばかりでなく，変換後の 2 乗の従ら分布がカイ二乗分布とした枠にも外れる。これは 6 章のべき正規分布の定義からわか るよらに入の符号が関係していることによる。この符号が関与しない様な変換

$$
\frac{1}{2 c}\left(\frac{X}{\mu}-1\right)\left\{F\left(1-\lambda, \beta ; 2 \beta ; 1-\frac{X}{\mu}\right)+F\left(1+\lambda, \beta ; 2 \beta ; 1-\frac{X}{\mu}\right)\right\}
$$

を考学る、明らかに $\lambda=0, \beta=1$ のとき，(1/c) $\log (X / \mu)$ に等しい.そこで，(7)で $\beta=1$ だけの条 
件を加えた

$$
\frac{1}{c} \xi_{\lambda}\left(\frac{X}{\mu}\right)=\frac{1}{2 c}\left(\frac{X}{\mu}-1\right)\left\{F\left(1-\lambda, 1 ; 2 ; 1-\frac{X}{\mu}\right)+F\left(1+\lambda, 1 ; 2 ; 1-\frac{X}{\mu}\right)\right\}
$$

を定義すると、これは初等関数であらわせ，

$$
\frac{1}{c} \xi_{\lambda}\left(\frac{X}{\mu}\right)= \begin{cases}\frac{1}{2 \lambda c}\left\{\left(\frac{x}{\mu}\right)^{\lambda}-\left(\frac{X}{\mu}\right)^{-\lambda}\right\} & \text { if } \lambda \neq 0 \\ \frac{1}{c} \log \frac{X}{\mu} & \text { if } \lambda=0\end{cases}
$$

となる。変換後の分布として $N(0,1)$ としたのであるから，

$$
\frac{1}{c} \xi_{\lambda}\left(\frac{X}{\mu}\right) \sim N(0,1)
$$

によって定義される確率変数 $X$ を考察することにする。変換 $(9)$ は対数正規分布 $(\lambda=0)$ と $\mathrm{B}-\mathrm{S}$ 分布 $(\lambda=1 / 2)$ を含んでいる。これらを保存して，且つ $X$ と $X^{-1}$ の分布が同じ分布族に入ってい る. 変換後の 2 乗の従う分布はカイ二乗分布であることは明らかである。このような变換が我多 の目的に望ましいものである。

次の目的は，逆数変換の一般化であるゼロでない任意のべき乗に関して閉じていて，且つ変換 後の 2 乗がカイ二乗分布に従うような分布を求めることである. B-S 分布は前者の性質は持たな いので考察の対象から外される。

(9)で定義される確率変数 $X$ の従ら分布の確率素分は

$$
\frac{1}{2} p\left(x ; \mu, c^{2}, 2 \lambda\right) d x+\frac{1}{2} p\left(x ; \mu, c^{2},-2 \lambda\right) d x
$$

で与えられる。ただし，

$$
p\left(x ; \mu, c^{2}, \lambda\right)=\frac{1}{\sqrt{2 \pi} c}\left(\frac{x}{\mu}\right)^{-1-\frac{\lambda}{2}} \exp \left\{-\frac{1}{2(\lambda c)^{2}}\left(\left(\frac{x}{\mu}\right)^{\frac{\lambda}{2}}-\left(\frac{x}{\mu}\right)^{-\frac{\lambda}{2}}\right)^{2}\right\} \frac{1}{\mu} .
$$

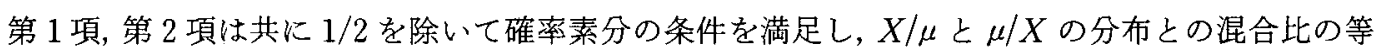
しい混合分布の確率素分である．第 1 項と第 2 項は入の正負に関して対称であることから，第 1 項に基づく新しい確率素分 $p\left(x ; \mu, c^{2}, \lambda\right) d x$ で定義される確率分布を考える。 $\lambda \rightarrow 0$ とすれば対 数正規分布， $\lambda=1$ とすればべき逆ガウス型分布の確率素分を与えることがわかる。

定義. (10) 式の確率素分 $p\left(x ; \mu, c^{2}, \lambda\right) d x, x>0 ; \mu>0, c>0, \infty>\lambda>-\infty$ 与穴られる分布 をべき逆ガウス型分布（power inverse Gaussian distribution）と呼び, 記号 $P I G\left(\mu, c^{2}, \lambda\right) て ゙$ 表わす。ただし， $\lambda=0$ は $\lambda$ のの極限で定義する。

定義式より $X \sim P I G\left(\mu, c^{2}, \lambda\right)$ ¿き，任意の正の夷数 $a$ および任意の実数 $k \neq 0$ に対して

$$
a X^{k} \sim P I G\left(a \mu^{k}, k^{2} c^{2}, \lambda / k\right)
$$

が成立する。特に $X^{\lambda} \sim I G\left(\mu^{\lambda},(\lambda c)^{2}\right)$ であり, 逆も成立する.べき逆がウス型分布の名はこの事

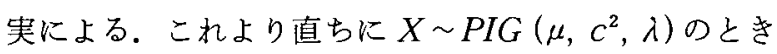




$$
\left\{\frac{(X / \mu)^{\lambda / 2}-(X / \mu)^{-\lambda / 2}}{\lambda}\right\}^{2} \sim c^{2} \chi^{2}(1)
$$

が示される，すなわち，(12)の左辺を損失関数とすれば,これはカイ二乗分布に従っている。な 扣，変換による標準正規分布との直接の関係はもはやない。

これで目的とした分布が得られたことになる，対数正規分布，逆ガウス型分布との関係を記号 で書けば $P I G\left(\mu, c^{2}, 1\right)=I G\left(\mu, c^{2}\right), P I G\left(\mu, c^{2}, 0\right)=L N\left(\mu, c^{2}\right)$ である.

次の章でべき逆がウス型分布の性質などについて述べる.な拉, 逆ガウス型分布の 3 母数化に よる一つの一般化はJ Jorgensen（1982）で論じられているが, ベき逆がウス型分布との直接の関係 は見いだされていない。

\section{4. ベき逆ガウス型分布 $P I G\left(\mu, c^{2}, \lambda\right)$}

\section{1. 性質と母数の意味}

ここではべき逆ガウス型分布の性質と母数の意味について述べる，定義式 (10)で条件 $\lambda>0 を$ つけた場合, 逆数の分布は $\lambda<0$ の場合となる。従って, 煩雑さを避けるために, これ以降 $\lambda>0$ と

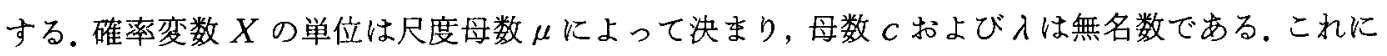

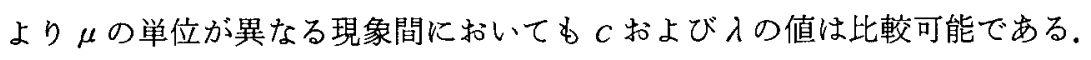

べき逆ガウス型分布は単峰であり，分布関数は

$$
\begin{aligned}
F(x)=P\{X \leq x\} & =\Phi\left(-\frac{1}{\lambda c}\left\{\left(\frac{x}{\mu}\right)^{-\lambda / 2}-\left(\frac{x}{\mu}\right)^{\lambda / 2}\right\}\right) \\
& +e^{2 /\left(\lambda^{2} c^{2}\right)} \Phi\left(-\frac{1}{\lambda c}\left\{\left(\frac{x}{\mu}\right)^{-\lambda / 2}+\left(\frac{x}{\mu}\right)^{\lambda / 2}\right\}\right)
\end{aligned}
$$

で与えられる。ここに， $(\cdot)$ は $N(0,1)$ の累積分布関数である。

べき逆ガウス型分布の密度関数の概形をつかむために, $\mu$ にって無名数化された $Y=X / \mu$ の 密度関数のグラフを描く. 各 $c=1 / 2,1,3 / 2$ に対して, $\lambda=0$ (対数正規分布) $, 1 / 2,1$ (逆ガウス型 分布), 3/2,2 として描いたグラフが図 1 , 図 2 および図 3 である。これらの図から次のような傾向 が読み取れる、cが 1 と比較して小さくなると, 最頻值は 1 に近づき，1 中心とした(すなわち $\mu$ を心とした）対称な分布に近くなる。この意味でcは非対称な分布の拡がりの程度を示す母 数であると考えられる．以後，cを「扗がり母数（spread parameter）」と呼ぶことにする. 任意

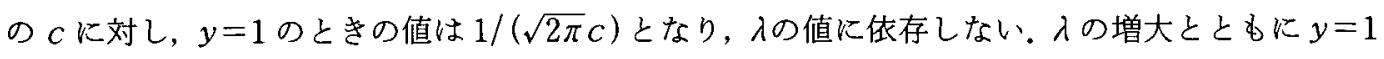
以上の確率は小さくなる傾向がある. 図 1 , 図 2 および図 3 での $y=1$ は, $\lambda=0$ のとき中央值,

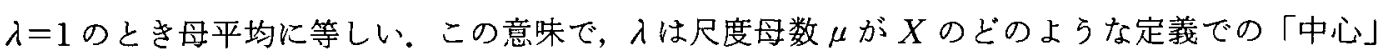
をあらわすかを定める母数であるとも考えられる.

$X \sim P I G\left(\mu, c^{2}, \lambda\right)$ とさ以下の性質を持つ. (11) で $a=\mu^{-k}$ とすれば $(X / \mu)^{k} \sim P I G\left(1, k^{2} c^{2}\right.$, $\lambda / k)$ となる。 そこで $k=c^{-1}$ とすれば $(X / \mu)^{1 / c} \sim P I G(1,1, \lambda c), k=\lambda$ とすれば $(X / \mu)^{\lambda} \sim P I G(1$, $\left.\lambda^{2} c^{2}, 1\right)$ となり,これはまた $(X / \mu)^{\lambda} \sim I G\left(1,(\lambda c)^{2}\right)$ と同等である.

また, $Y=\{1 /(\lambda c)\}\left\{(X / \mu)^{\lambda / 2}-(X / \mu)^{-\lambda / 2}\right\}$ の確率密度関数は

$$
\left\{1-y\left(y^{2}+\frac{4}{(\lambda c)^{2}}\right)^{-1 / 2}\right\} \cdot \frac{1}{\sqrt{2 \pi}} \exp \left\{-\frac{1}{2} y^{2}\right\}, \quad-\infty<y<\infty .
$$


p.d.f. of PIG (c= .5)

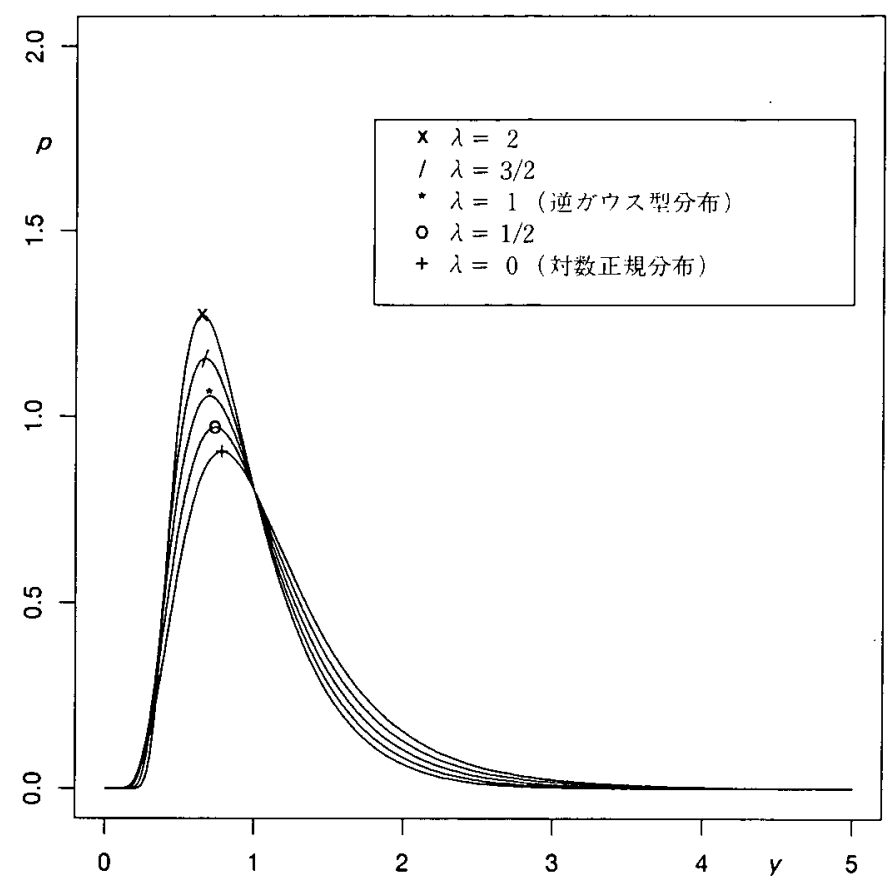

図 $1 X \sim P I G\left(\mu,\left(\frac{1}{2}\right)^{2}, \lambda\right)$ $X$ その $Y=X / \mu$ の密度関数のグラフ

これより $Y^{2} \sim \chi^{2}(1)$ が示せる. 従って， $T=|Y|$ は自由度1のカイ分布（folded Gaussian）に 従う. 更に, $\lambda \log (X / \mu)$ の分布は $P I G$ の定義式より直ちに導出され，

$$
\begin{gathered}
E\left(\log \left(\frac{X}{\mu}\right)^{\lambda}\right)=\exp \left\{\frac{2}{\lambda^{2} c^{2}}\right\} \cdot E_{i}\left(-\frac{2}{\lambda^{2} c^{2}}\right),(=A \text { とおく }) \\
E\left(\left\{\left(\frac{X}{\mu}\right)^{\lambda}-1\right\} \log \left(\frac{X}{\mu}\right)^{\lambda}\right)=-2 A
\end{gathered}
$$

を得る。ただし， $E_{i}$ は積分指数関数 $E_{i}(t)=\int_{-\infty}^{t} x^{-1} e^{x} d x$ である。これより

$$
E\left(\left\{\left(\frac{X}{\mu}\right)^{\lambda}+1\right\} \log \left(\frac{X}{\mu}\right)^{\lambda}\right)=0
$$

となる。をた， $X \sim P I G\left(\mu, c^{2}, \lambda\right)$ のを，任意の㬰数 $k$ に対し

$$
E\left(X^{k}\right)=\mu^{k} \frac{1}{\lambda c} \sqrt{\frac{2}{\pi}} \exp \left\{\frac{1}{\lambda^{2} c^{2}}\right\} \cdot K_{(k / \lambda)-(1 / 2)}\left(\frac{1}{\lambda^{2} c^{2}}\right)
$$

である.ただし， $K$ は変形された第 2 種ベッセル関数である.

対数正規分布の性質が，確率変数の対数変換により正規分布の性質を用いて調べることができ

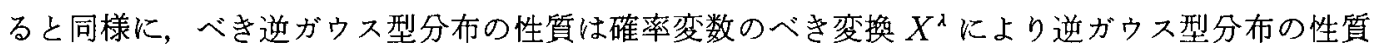
を用いて調べられる。しかし対数正規分布と異なりこの分布を特別な場合として含んでいるた め，変換に未知母数が混入している. 


\section{p.d.f. of PIG $(c=1)$}

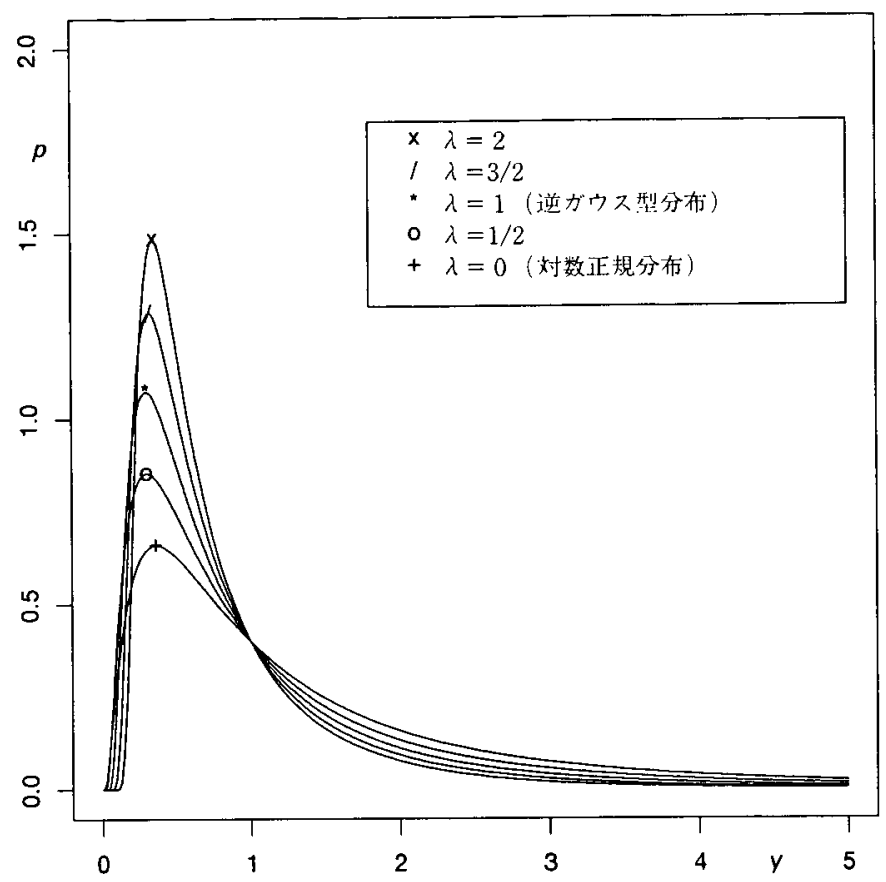

図 $2 X \sim P I G\left(\mu, 1^{2}, \lambda\right)$ $\boldsymbol{X}$ ときの $Y=X / \mu$ の密度関数のグラフ

\section{2. 損失関数}

2 章で損失関数について論じたが，ここではべき逆ガウス型分布に和ける損失関数とそれに関 する特性量について議論する。

（13）式の特別な場合として,

$$
\begin{aligned}
& E\left(X^{\lambda}\right)=\mu^{\lambda}, \\
& E\left(X^{2 \lambda}\right)=\mu^{2 \lambda}\left\{1+(\lambda c)^{2}\right\}, \\
& E\left(X^{-\lambda}\right)=\mu^{-\lambda}\left\{1+(\lambda c)^{2}\right\}
\end{aligned}
$$

より

$$
\begin{gathered}
X^{\lambda} \text { の母変動係数 }=\frac{\sqrt{\operatorname{Var}\left(X^{\lambda}\right)}}{E\left(X^{\lambda}\right)}=\lambda c, \\
E\left(\left(\frac{X}{\mu}\right)^{\lambda}+\left(\frac{X}{\mu}\right)^{-\lambda}-2\right)=(\lambda c)^{2}=\operatorname{Var}\left(\left(\frac{X}{\mu}\right)^{\lambda}\right)
\end{gathered}
$$

が得られる。これを変形すると

$$
\begin{aligned}
& E\left(\left\{\frac{(X / \mu)^{\lambda / 2}-(X / \mu)^{-\lambda / 2}}{\lambda}\right\}^{2}\right) \\
& =\operatorname{Var}\left(\frac{(X / \mu)^{\lambda}-1}{\lambda}\right)=\left(\frac{X^{\lambda} \text { の変動係数 }}{\lambda}\right)^{2}=c^{2}
\end{aligned}
$$




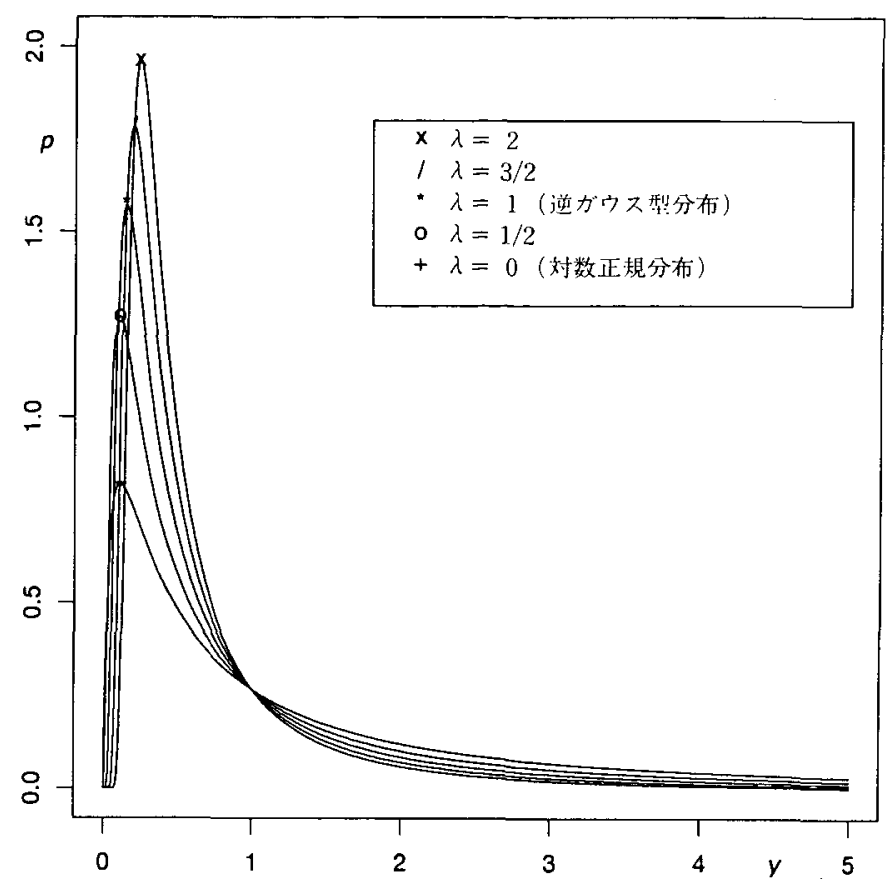

図 $3 X \sim P I G\left(\mu,\left(\frac{3}{2}\right)^{2}, \lambda\right)$ $\boldsymbol{X} \sim$ きの $Y=X / \mu$ の密度関数のグラフ

となり，入で基準化したいくつかの「バラッキ」を示す值が $c^{2}$ である。さきにcを払がり母数と 呼んだ一つの理由である。

さて，(9)は $(1 / c) \xi_{\lambda}(X / \mu)$ の心0からのズレを表わす分布として $N(0,1)$ を考㝋て和り， $\left\{(1 / c) \xi_{\lambda}(X / \mu)\right\}^{2}$ が $\chi^{2}(1)$ に従うから，ズレのバラッキを表わす分布としてカイ二乗分布を考え ていることになる。ここで $X \sim P I G\left(\mu, c^{2}, \lambda\right)$ のをき $(1 / c) \xi_{\lambda}(X / \mu)$ はもはや $N(0,1)$ に従わない が，(12）で示したように $\left\{(1 / c) \xi_{\lambda}(X / \mu)\right\}^{2}$ は $\chi^{2}(1)$ に従う。すなわち,ズレのバラッキを表わす分 布は保存されている. 従って尺度母数 $\mu$ を推定するとさの損失関数として

$$
\frac{1}{\lambda^{2}}\left\{\left(\frac{\widehat{\mu}}{\mu}\right)^{\lambda}+\left(\frac{\hat{\mu}}{\mu}\right)^{-\lambda}-2\right\}
$$

を考えることができる、ただし，べき逆ガウス型分布に於ける尺度母数の推定にこの損失関数を 用いると，他のもら一つの未知母数 $\lambda$ に依存しているので解析が困難である.

ここで, (15)で $\lambda \rightarrow 0$ のき, 寸なわち対数正規分布の場合には尺度母数 $\mu$ の推定量 $\widehat{\mu}$ の損失 関数として $(\log \widehat{\mu}-\log \mu)^{2}, \quad \lambda=1$ のとき，すなわち逆ガウス型分布の場合のそれに対しては

$$
L(\bar{\mu}, \mu)=\frac{\widehat{\mu}}{\mu}+\frac{\mu}{\widehat{\mu}}-2=\left(\sqrt{\frac{\widehat{\mu}}{\mu}}-\sqrt{\frac{\mu}{\widehat{\mu}}}\right)^{2}
$$

を導く。これらは 2 章で紹介したものである.（16)式を用いた推定は Hirano (1984), Hirano and Iwase (1989), Hirano and Iwase (1990) で議論している. 
次に $L(\bar{\mu}, \mu)$ を用いた結果や幾つかの特性量について述べる. $X_{1}, X_{2}, \cdots, X_{n} \sim i . i . d . L N(\mu$, $\left.c^{2}\right)$ のき, 幾何平均 $\bar{X}_{G}$ は母中央值 $\mu$ の中央値不偏推定量であり, $\bar{X}_{G} \sim L N\left(\mu, c^{2} / n\right)$ より

$$
E\left(\frac{\bar{X}_{G}}{\mu}+\frac{\mu}{\bar{X}_{G}}-2\right)=2\left(e^{c^{2 /(2 n)}}-1\right) \doteq \frac{c^{2}}{n}, \quad\left(\frac{c^{2}}{n} \ll 1\right)
$$

である. $X_{1}, X_{2}, \cdots, X_{n} \sim i . i . d . I G\left(\mu, c^{2}\right)$ のとき, 標本平均 $\bar{X}$ は母平均 $\mu$ の不偏推定量であり, $\bar{X} \sim I G\left(\mu, c^{2} / n\right)$ より

$$
E\left(\frac{\bar{X}}{\mu}+\frac{\mu}{\bar{X}}-2\right)=\frac{c^{2}}{n}
$$

である。

$$
\begin{aligned}
& X \sim P I G\left(\mu, c^{2}, \lambda\right) \text { のとき, } \\
& \qquad \begin{array}{l}
E\left(\frac{X}{\mu}+\frac{\mu}{X}-2\right) \\
\quad=\frac{1}{\lambda c} \sqrt{\frac{2}{\pi}} \exp \left\{\frac{1}{\lambda^{2} c^{2}}\right\} \cdot\left\{K_{(1 / \lambda)-(1 / 2)}\left(\frac{1}{\lambda^{2} c^{2}}\right)+K_{(1 / \lambda)+(1 / 2)}\left(\frac{1}{\lambda^{2} c^{2}}\right)\right\}-2
\end{array}
\end{aligned}
$$

となることが $(13)$ より直接示せる。 $\lambda c \ll 1$ のとき近似的に $c^{2}$ に等しい。これは， $P I G\left(\mu, c^{2}, \lambda\right)$ の $\mu$ に対寸る損失関数としては本来 (15) を用いるのだが，（16)を用いたことによる相違である. $\lambda=1$ のときに（12)より正確に $c^{2}$ に等しい。

尺度母数 $\mu$ を対数変換して $\log \mu$ を位置母数と考えた場合,

$$
E\left(\left\{\frac{(X / \mu)^{\lambda}+1}{2}\right\} \log X\right)=\log \mu
$$

が成り立つ。す，前節で述べたように

$$
E\left(\frac{(X / \mu)^{\lambda}-1}{\lambda} \log \frac{X}{\mu}\right)=-\frac{2 A}{\lambda^{2}}=\frac{2}{\lambda^{2}}\left\{-\exp \left(\frac{2}{\lambda^{2} c^{2}}\right) \cdot E_{i}\left(-\frac{2}{\lambda^{2} c^{2}}\right)\right\}
$$

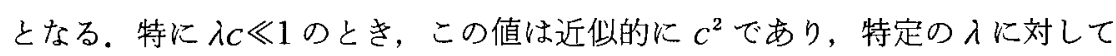

$\lambda=1$ (逆ガウス型分布) のとき, $E\left(\left\{\frac{X}{E(X)}-1\right\} \log \frac{X}{\mu}\right) \doteq c^{2},(c \ll 1)$

$\lambda \rightarrow 0$ (対数正規分布) $の$ 之き, $E\left(\left\{\log \frac{X}{\mu}\right\}^{2}\right)=c^{2}$

が成立する。これらと同じように次のTheil 倸数も $c$ と関連がある：

$$
E\left(\frac{X}{E(X)} \log \frac{X}{E(X)}\right)= \begin{cases}-\exp \left\{\frac{2}{c^{2}}\right\} E_{i}\left(-\frac{2}{c^{2}}\right) \doteq c^{2} / 2, & \text { if } X \sim I G\left(\mu, c^{2}\right), \\ c^{2} / 2, & \text { if } X \sim L N\left(\mu, c^{2}\right) .\end{cases}
$$

Theil 係数については Theil (1967) の 4 章を参照されたい.なお， $X \sim G a\left(\mu, c^{2}\right)$ のきこれ らの期待値がどうなるかを付録に載せた。

\section{3. モーメント法によるPIG $\left(\mu, c^{2}, \lambda\right)$ の推定}

モーメント法によるPIG $\left(\mu, c^{2}, \lambda\right)$ の母数の推定について考察する。ここでは最尤推定量などと の比較は議論しない. 大きさ $n$ の標本を $X_{1}, X_{2}, \cdots, X_{n}$ とし, $\lambda$ の推定を考学る。ここで $\bar{X}_{\lambda}$ 
$=\frac{1}{n} \sum_{i=1}^{n} X_{i}^{\lambda}$ と定義すれば, (14) から $E\left(X^{2 \lambda}\right)=\left\{E\left(X^{\lambda}\right)\right\}^{3} \cdot E\left(X^{-\lambda}\right)$ を得る.モーメント法を用い るので $g(\lambda)=\bar{x}_{2 \lambda}-\left(\bar{x}_{\lambda}\right)^{3} \cdot \bar{x}_{-\lambda}$ と定義する. 標本 $x_{1}, x_{2}, \cdots, x_{n}$ を固定し, 各 $\lambda$ について $g\left(\lambda^{*}\right)=0$ を満たす $\lambda^{*}$ を求める。これを $\lambda$ の推定値とする。積率の関係式より $\left(X^{2} \text { の母変動係数 }\right)^{2}$ $=E\left(X^{\lambda}\right) \cdot E\left(X^{-\lambda}\right)-1$ であるから, $g\left(\lambda^{*}\right)=0$ を見つけることは， $x_{i}^{\lambda}$ の標本変動係数の二乗之 $\left(x_{i}{ }^{\lambda}\right.$ の標本平均 $) /\left(x_{i}{ }^{\lambda}\right.$ の調和平均 $)-1$ とが一致する $\lambda$ を見つける作業になっている。このように して得られた $\lambda^{*}$ で

$$
\begin{gathered}
\mu^{*}=\left(\bar{x}_{\lambda^{*}}\right)^{1 / \lambda^{*}} \\
\left(c^{*}\right)^{2}=\frac{\bar{x}_{\lambda^{*}} \cdot \bar{x}_{-\lambda^{*}-1}}{\left(\lambda^{*}\right)^{2}}
\end{gathered}
$$

により $\mu$ 抢よび $c^{2}$ の推定がなされる。なお， $n \geq 3$ に対して $g\left(\lambda^{*}\right)=0$ を満たす $\lambda^{*}$ の存在および 一意性は証明できていない， $n=2$ に対しては $g\left(\lambda^{*}\right)<0$ となり，解のないことがわかる.

\section{5. 乗法的外乱の加わる曲線回帰モデル}

1 章でデータが第 1 象限にしか存在し得ない例として，あらかじめ定められた区間を車が交通 の流れに沿って移動するに要する時間（旅行時間）をとりあげた。測定区間が長くなればそれだ け旅行時間は大きくなるばかりでなく，バラッキも大きくなる。しかし，この旅行時間のバラッ キの増大はいわば比例拡大されたものであり，見かけ上のバラッキの増大であるとる考它られる。 この意味で例えば変動係数は旅行時間の本質的なバラッキであるととらえることができる。 Iwase（1989）は原点を通る直線回帰モデル

$$
Y_{i}=\beta x_{i} \cdot \varepsilon_{i}, \quad \varepsilon_{i} \sim \text { i.i.d. } I G\left(1, c^{2}\right)
$$

について考察した. $Y_{i}$ の母平均は $\beta x_{i}$ であり, 母変動係数は $c$ であり, 説明変数 $x_{i}$ の值には依 存しない.また $c$ は回帰直線からのずれのバラッキを示す母数である.モデル (17)の旅行時間へ の具体的な適用は浦野, 岩瀬(1991)でなされている。ここではこのモデルの一つの拉張を試みる。

最初に，原点を通る曲線回帰モデル

$$
Y_{i}=\left(\beta x_{i} \cdot \eta_{i}\right)^{a}, \quad \eta_{i} \sim \text { i.i.d. } \operatorname{PIG}\left(1, c^{2}, \lambda\right)
$$

を考察する.（11）よりこのモデルは

$$
Y_{i}=\left(\beta x_{i}\right)^{\alpha} \cdot \varepsilon_{i}, \quad \varepsilon_{i} \sim \text { i.i.d. } \operatorname{PIG}\left(1,(\alpha c)^{2}, \frac{\lambda}{\alpha}\right)
$$

に等しい. 誤差 (比) 項 $\eta_{i}$ 扎よび $\varepsilon_{i}$ は無名数である。ここで, $\left(x_{i}, y_{i}\right)$ の単位がどのような現象 であっても $\alpha, c, \lambda$ 燻名数であり, 比較が可能である. $\beta$ の単位は $Y_{i}$ の尺度母数之 $x_{i}$ の尺度

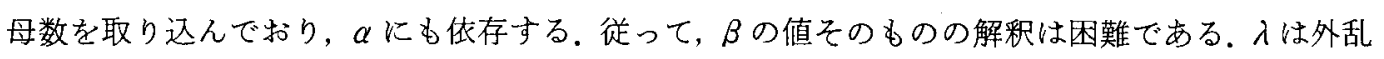

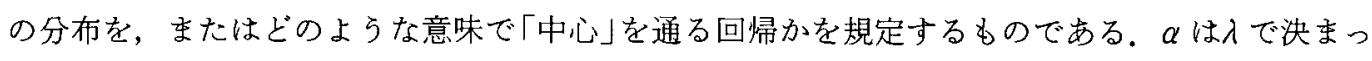
た「中心」の回㷌の構造を規定するものである，cはそのような $a$ に依存しない基本となる外乱 のバラッキを示す母数である.

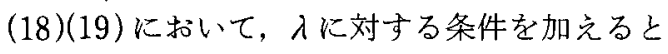

(i ) $\lambda=0 ; \varepsilon_{i} \sim \operatorname{LN}\left(1,(\alpha c)^{2}\right)$, 
(ii) $\lambda=\alpha ; \varepsilon_{i} \sim I G\left(1,(\alpha C)^{2}\right)$ となる.

(i)の場合で $\alpha=1$ (直線回㷌) としたとき岩瀬, 瀬戸（1990），一般の $\alpha$ としたとき岩瀬, 瀬戸 （1991）で考察されている.（ii）の場合で $\alpha=1$ (直線回㷌)としたときIwase (1989), 浦野, 岩瀬 (1991) で考察されている。ここでは一般の $\alpha$ について，すなわち曲線回㷌モデル

$$
Y_{i}=\left(\beta x_{i}\right)^{a} \cdot \varepsilon_{i}, \quad \varepsilon_{i} \sim \text { i.i.d. } I G\left(1,(\alpha c)^{2}\right)
$$

を考察する， $Y_{i}$ の母変動係数は $Y_{i}$ の母平均の増加率を決める $\alpha$ に比例して大きくなるが，この aによる見かけ上のバラッキの増大を除去したバラッキを示すのが ル(20)の母数の推定はべき逆がウス型分布の母数推定に帰着される.実際, モデル $(20)$ は $Y_{i} / x_{i}^{\alpha}$ $=\beta^{\alpha} \cdot \varepsilon_{i} \sim$ i.i.d. IG $\left(\beta^{\alpha},(\alpha c)^{2}\right)$ すなわち, $Y_{i}^{1 / \alpha} / x_{i} \sim i . i . d . P I G\left(\beta, c^{2}, \alpha\right)$ に等しい.

そこで，4.3 節で述べたモーメント法による推定を適用するために

$$
\bar{Z}_{\alpha}=\frac{1}{n} \sum_{i=1}^{n} \frac{Y_{i}}{x_{i}^{\alpha}}, \quad \bar{Z}_{-\alpha}=\frac{1}{n} \sum_{i=1}^{n} \frac{x_{i}^{\alpha}}{Y_{i}}, \quad \bar{Z}_{2 a}=\frac{1}{n} \sum_{i=1}^{n} \frac{Y_{i}{ }^{2}}{x_{i}{ }^{2 \alpha}}
$$

とし, $g(\alpha)=\bar{Z}_{2 \alpha}-\left(\bar{Z}_{a}\right)^{3} \cdot \bar{Z}_{-\alpha}$ と拈く. 標本 $\left(x_{i}, Y_{i}\right)$ より $g\left(\alpha^{*}\right)=0$ なる $\alpha^{*}$ を求める。これによ $\eta$

$$
\beta^{*}=\left(\bar{Z}_{\alpha^{*}}\right)^{1 / \alpha^{*}}, \quad\left(c^{*}\right)^{2}=\frac{\bar{Z}_{\alpha^{*}} \cdot \bar{Z}_{-\alpha^{*}-1}}{\left(\alpha^{*}\right)^{2}}
$$

として, $\beta, c^{2}$ が求められる.

モデル（20）で特に $\alpha=1$ の場合，すなわち原点を通る回帰直線

$$
Y_{i}=\beta x_{i} \cdot \varepsilon_{i}, \quad \varepsilon_{i} \sim \text { i.i.d. IG }\left(1, c^{2}\right)
$$

に执いて

$$
Q=\frac{1}{n} \sum_{i=1}^{n}\left(\sqrt{\varepsilon_{i}}-\frac{1}{\sqrt{\varepsilon_{i}}}\right)^{2}=\frac{1}{n} \sum_{i=1}^{n}\left(\varepsilon_{i}+\frac{1}{\varepsilon_{i}}-2\right) \text { の最小化 }
$$

の規則で $\beta$ の推定量 $\hat{\beta}$ を求める。そのとき

$$
Q(\beta)=\frac{1}{\beta n} \sum_{i=1}^{n} \frac{Y_{i}}{x_{i}}+\frac{\beta}{n} \sum_{i=1}^{n} \frac{x_{i}}{Y_{i}}-2
$$

เり

$$
\hat{\beta}=\left\{\frac{\sum_{i=1}^{n} Y_{i} / x_{i}}{\sum_{i=1}^{n} x_{i} / Y_{i}}\right\}^{1 / 2}
$$

を得る。原理 (21) は, いわば加法的に外乱が加わる正規分布モデルでの最小二乗法に相当するも のであり，乗法的に外乱が加わるモデルでの 1 つの推定原理を与克ている.

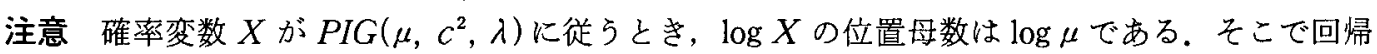
モデル (20)で $\log \varepsilon_{i}$ に最小二乗法を適用すれば $\lambda, \beta, c$ の推定量は容易に作れる.なお，(16)式 の前後で述べた損失関数についての記述に注意されたい.

\section{6. 補 足}

2 章でガンマ分布, 対数正規分布, B-S 分布, 逆ガウス型分布の確率素分を示した.これらは B- 
$\mathrm{S}$ 分布を除くと通常の場合と異なった母数の入れ方をしていた。一般に各分布に対して母数の入 れ方は何通りかの表現があり，それぞれの由来があるだろう。本稿で述べたような単位を持つ計 測值の場合には母数の入れ力に注意すべきである。逆ガウス型分布の場合, Chhikara and Folks （1989）上異なるが，本稿でその考方を述べた，対数正規分布についても同様である，通常では $\log X \sim N\left(\mu, \sigma^{2}\right)$ のき，Xの従う分布として定義されている。この場合 $\mu$ の解釈， $\sigma^{2}$ が無名数 であることの解釈，またそれぞれの意味付けが難しい.その点（3）式による定義は明確になってい る.

べき正規分布についても同様である。べき正規分布は通常 $\left(X^{\lambda}-1\right) / \lambda \sim$ truncated $N\left(\mu, \sigma^{2}\right)$ の とき，Xの従う分布として定義されている(この分布については，例えば本誌松原，後藤（1980） を参照されたい）。この場合も同様に母数の単位や解釈に難点がある。(6)式によれば正值確率変 数 $X$ と, 母数 $\mu>0, c>0, \lambda \neq 0$ に対し, $(1 / c) \cdot\left\{(X / \mu)^{\lambda}-1\right\} / \lambda$ は $(\mathrm{i}) \lambda>0$ のとき, $N(0,1)$ の

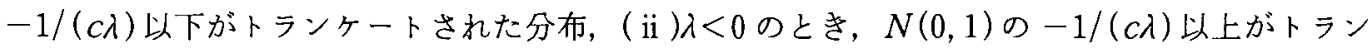
ケートされた分布，に従うとするとき，Xの従ら分布をべさ正規分布といら．その確率素分は

$$
\frac{1}{\Phi(1 /(|\lambda| c))} \cdot \frac{1}{\sqrt{2 \pi} c}\left(\frac{x}{\mu}\right)^{\lambda-1} \exp \left\{-\frac{1}{2 c^{2}}\left(\frac{(x / \mu)^{\lambda}-1}{\lambda}\right)^{2}\right\} \frac{d x}{\mu}, \quad x>0
$$

で与えられる．この定義によれば， $c$ 括よび入は無名数であり，尺度母数 $\mu$ の単位にかかわらず 比較が可能である。

\section{付 録}

$X \sim G a\left(\mu, c^{2}\right)$ のさ

$$
E\left(X^{k}\right)=\left(c^{2} \mu\right)^{k} \frac{\Gamma(s+k)}{\Gamma(s)} .
$$

ただし， $k$ は非負の任意の央数， $s=1 / c^{2}$ である。これを用いると

$$
E(X)=\mu, \quad \operatorname{Var}(X)=c^{2} \mu^{2}, \quad \text { 変動係数 }=c
$$

を得る。るた，

$$
E\left(\left(\frac{X}{\mu}\right)^{k} \log \frac{X}{\mu}\right)=\frac{\Gamma(s+k)}{\Gamma(s)}\left(\frac{1}{s}\right)^{k}\{\psi(s+k)-\log s\} .
$$

ただし $, k>-s, s=1 / c^{2}, \quad \phi(\alpha)=\frac{d}{d \alpha} \log \Gamma(\alpha)$ である.これを用いると

$$
E\left(\left(\frac{X}{\mu}-1\right) \log \frac{X}{\mu}\right)=c^{2}
$$

を得る、積率母関数は

$$
E\left(e^{t X}\right)=\left(1-c^{2} \mu t\right)^{-1 / c^{2}}, \quad t<\frac{1}{c^{2} \mu}
$$

である.さらに,

$$
E\left(\frac{X}{\mu}-1-\log \frac{X}{\mu}\right)=\log \frac{1}{c^{2}}-\psi\left(\frac{1}{c^{2}}\right) \simeq c^{2},(c \ll 1)
$$

である. 
謝 辞 本稿は, 科学研究費総合 $\mathrm{A}\lceil$ 統計学の数理的基礎と諸分野への応用に関する研究」による シンポジゥム「正の值をとる連続分布に関する研究」(1989.11.20-22 於大阪大学基礎工学部)の 予稿を書き改めたものである。統計数理研究所の清水良一氏にはシンポジゥムへの参加を勧めて 下さり，草稿の不備な点を指摘していただいた。 また投稿論文に対して，查読者から建設的な助 言をいただいた。これらをもとに書き改めることができた。ここに記して謝意を表したい。この 研究は一部, 昭和 63 年度, 平成 1,2 年度統計数理研究所共同研究の援助による成果である.

\section{参考 文 献}

Birnbaum, Z.W. and Saunders, S.C. (1969): A new family of life distributions, J. Appl. Prob. 6, 319-327. Chhikara, R.S. and Folks, J.L. (1989): The Inverse Gaussian Distribution: Theory, Methodology, and Applications, Statistics: textbooks and monographs, Vol. 95, Marcel Dekker, New York.

Hirano, K. (1984): A preliminary test procedure for the scale parameter of exponential distribution when the selection parameter is unknown, Ann. Inst. Statist. Math., A 36, 1-9.

Hirano, K. and Iwase, K. (1989): Minimum risk scale equivariant estimator : Estimating the mean of an inverse Gaussian distribution with known coefficient of variation, Commun. in Statist., Theory and Methods 18, 189-197.

Hirano, K. and Iwase, K. (1990): On Fisher's problem of the Nile, Research Memorandum No. 389, Inst. Statist. Math.

Jørgensen, B. (1982): Statistical Properties of the Generalized Inverse Gaussian Distribution, Lecture Notes in Statistics, Vol. 9, Springer-Verlarg, New York.

Iwase, K. (1989): Linear regression through the origin with constant coefficient of variation for the inverse Gaussian distribution, Commun. in Statist., Theory and Methods 18, 3587-3593.

岩瀬晃盛, 瀬戸信也 (1990)：大気中アルミニュウム濃度とスカンジム濃度との統計的特性, 広島大学工学部 研究報告 第 38 巻 第 2 号 153-161.

岩瀬晃盛, 瀬戸信也 (1991)：対数正規誤差に基づく原点を通る曲線回㷌, 広島大学工学部研究報告 第 39 巻 第 2 号 111-118.

Kullback, S. (1959): Information Theory and Statistics, Wiley, New York.

松原義弘, 後藤昌司 (1980)：ベキ正規分布に基づく生存時間データの曲線回㷌，応用統計学 9，43-51。

Shuster, J. (1968): On the inverse Gaussian distribution function, J. Amer. Statist. Assoc. 63, 1514-1516.

Theil, H. (1967): Economics and Information Theory, North Holland, Amsterdam.

津村善郎, 㴊勝 学, 筑林昭明 (1988): 社会統計入門, 東京大学出版会.

浦野 隆, 岩瀬晃盛（1991）：車両走行時間の統計的特性一逆ガウス型分布誤差に基づく直線回帰の応用一，交通 工学 第 26 巻 2 号 8-16. 